\title{
Virtual Reality Game for Introducing Pencak Silat
}

\author{
https://doi.org/10.3991/ijim.v15i01.17679 \\ Jansen Sampurna, Wirawan Istiono ${ }^{\square}{ }^{\varpi}$, Alethea Suryadibrata \\ Universitas Multimedia Nusantara, Jakarta, Indonesia \\ wirawan.istiono@umn.ac.id
}

\begin{abstract}
The culture of the Indonesians is truly diverse and widely known by the worldwide community. One of the cultures is the martial art called pencak silat. Pencak silat is considered as a martial art because each movement includes art. There are many Indonesians pay less attention to this martial art. Therefore, in this paper, we try to create media to introduce pencak silat. One of the media that can be used is a rhythm game with virtual reality technology. A virtual reality rhythm game is played by hitting the incoming object according to the song being played. The player can hit that object by using pencak silat's movement corresponding to the incoming object. The movements used in this game are "pukulan lurus", "pukulan sangkal", "tebangan", and "dobrakan". We evaluate this game by using Hedonic-Motivation System Adoption Model or HMSAM modeling to determine the player's satisfaction level. The behavioral intention to use and immersion obtained using HMSAM is $78.61 \%$ and $77 \%$, respectively.
\end{abstract}

Keywords - Game, HMSAM, Martial Arts, Pencak Silat, Virtual Reality

\section{$1 \quad$ Introduction}

Indonesian culture is remarkably diverse. Every region in Indonesia has its own culture and tradition. These cultures need to be protected and conserved. One of the many ways that can be done is by introducing these cultures to other people. Special attention is needed to keep Indonesian culture exist for many generations ahead. Iskandar said that Indonesian citizens should take a stand to preserve Indonesian culture's values and beliefs to survive in the era of globalization [1]. It means Indonesian people need to take action as soon as possible. Weking attempt to preserve traditional Indonesian food using Augmented Reality [2]. Their research shows that the application is helpful and very interactive to introduce traditional Indonesian food to the other community. This research shows a way how to preserve Indonesian culture with the use of technology. Therefore, besides traditional food, Indonesian culture can be introduced to the next generation citizen using technology.

Pencak silat is one of many traditional Indonesian martial art. Pencak silat has been listed by UNESCO (United Nations Educations, Scientific and Cultural Organization) as one of the intangible cultural heritage at the 14th session in Bogota, Colombia [3]. However, the learning rate of pencak silat in Indonesia is quite low. Many parents did not allow their children to learn pencak silat because they are afraid that pencak silat is 
not educative [4]. This makes a negative point of view to pencak silat, which is one of our listed intangible cultural heritage by UNESCO. Some researchers try to use the game for a specific purpose, such as for simulation or education. It is believed that the game can make the application more interactive. Hence, this feature is one of the advantages of the game from the other media. Istiono has successfully built a game for educational purposes, where the game is used to educate basic algorithm and programming. This research shows that $83.87 \%$ of users agree that this game is helpful [5]. Other researchers built an education game for learning arithmetic. The game was built with Augmented Reality technology. The researchers conclude that the augmented reality game improves a student's learning motivation. That means technology is often used as a medium for learning [6]. Another technology that is implemented by many researchers and game developers is virtual reality. Virtual reality is considered as a technology that can provide more real user experience. Virtual reality is also implemented to introduce fish type in kindergarten. The result of user experience testing is $89.8 \%$, and it is considered excellent [8]. This research will use a gyroscope and accelerometer to allow players to feel as if they were exploring virtual hallways for real sensation [7]. This research aims to introduce Indonesian martial arts, namely pencak silat, to the public, using virtual reality game technology.

\section{Literature Review}

\subsection{Gamification}

Gamification is a process to improve service to achieve a gameful experience so that users are motivated to increase value creation. Gamification is usually applied to learning applications to increase user interest and user satisfaction with the application [15]. In the implementation, gamification can be applied using game dynamics to create attractive experiences and motivate users to use the application. Furthermore, several gamification elements are often used in an application, such as goals or targets, challenges, competition, rewards or achievements, user engagement, and learning elements [16].

Papadakis in his research using the gamification method to supporting an introductory programming course [15]. Moreover, the result has shown that student performance, in general, has not been too positively affected; however, on the other side, their involvement has been positively affected [17-20]. In virtual reality game research, the introduction of pencak silat also applies some of the elements above to attract user interest and introduce and learn about pencak silat originating from Indonesia.

\subsection{Pencak silat}

Pencak silat is considered as Indonesian traditional martial arts. According to $\mathrm{Aj}$ [4], martial arts contain two basic words, namely art and self-defense. The word "art" refers to pencak silat, which has a beautiful movement system while defending itself in the 
form of patterns of attack or pattern of steps. The word "martial" is the main thing in silat to use the techniques, rules, and philosophies in one's silat [4]. The technique of using the arm on pencak silat as an attack tool is called a punch. Hand attack techniques can be described as follows [9].

- Pukulan lurus: A straight punch is like a fist by clenching one hand and swinging it forward while the other hand covers or protects the chest.

- Pukulan sangkal/ pukulan bandul: Pukulan sangkal can be done by clenching your fists and pointing the fists up. Pukulan sangkal is carried out by swinging the arm from the bottom up.

- Tebangan: Tebangan can be done by swinging the hand in an open position. The trajectory of this attack technique can be done from the outside in or from the inside out. This technique can use both hands to attack.

- Dobrakan: Dobrakan is an attack that uses both open palms towards the opponent and targets the opponent's chest.

\subsection{Fisher yates shuffle}

Richard Durstenfield introduced modern methods in 1964 for use in computers. Modern fisher-yates shuffle algorithm is more efficient in reducing the complexity of the algorithm to $\mathrm{O}(\mathrm{n})$ when compared to other methods that have nested-loop so that it has a complexity of $\mathrm{O}(\mathrm{n} 2)$ [10]. The steps to use this method is; first, prepare an array of $\mathrm{N}$ elements, and after that raise one random number from 1 to $\mathrm{N}$ elements that have not been exchanged, next, exchange the array element in the element of the random number with the element to $\mathrm{N}$ and last step, repeat from step two until the entire array is selected.

\section{$3 \quad$ Methodology}

\subsection{System design}

The application is a single-player rhythm game. Each level has a different song. Players are expected to be able to destroy objects that move towards the position of the player. The object's initial position is located randomly by using the fisher yates shuffle algorithm. This randomization is used to make the objects starting location more unpredictable and make the game more interesting. The game only randomized the starting location of an object and not effects the pencak silat movement order each level or music chart. The players need to perform pencak silat movement according to what is displayed by the object to get a score. These pencak silat movement examples will be available in the tutorial menu in the form of video. This video is provided by someone who knows well about pencak silat on YouTube. The video creator name will be added to the credits page. 


\subsection{Top view game design}

Players are placed in front of the game track. The scoreboard is located on the right side of the lane track. The user interface is located in front of the player. The game track is used as the lane of the objects move toward the player. If the player hits the object when it reaches the timing scorer's position, the player will get a maximum score of 100 points. Otherwise, the player will only get 50 points. The scoreboard is on the right side of the track, which provides score and combo information that has been obtained by the player. Fig 1 shows the game design of pencak silat virtual reality.

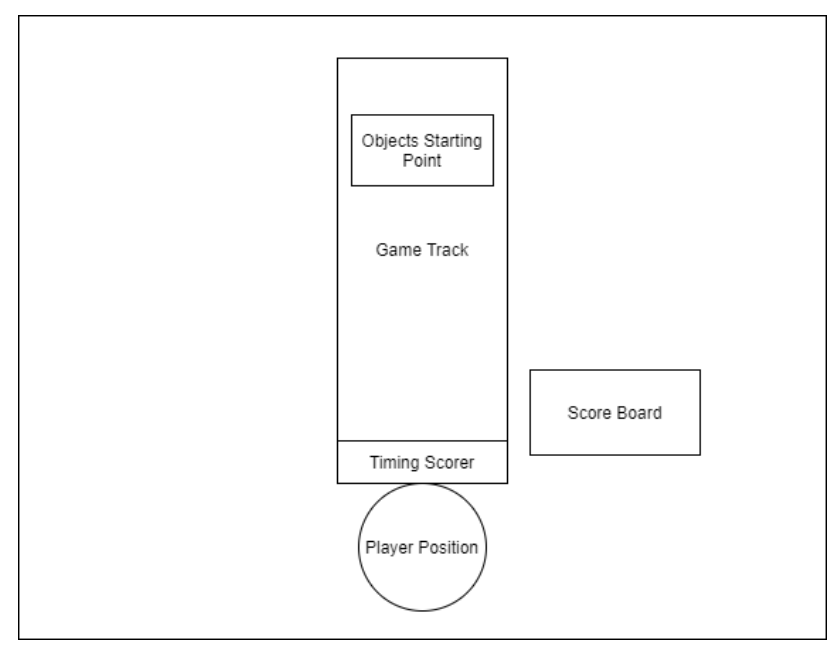

Fig. 1. Top view game design pencak silat

\subsection{Hedonic-motivation system adoption model}

The Hedonic-motivation system adoption model is used to evaluate how the user feels about the game. The questionnaire will contain statements based on the modeling of the HMSAM (Hedonic-Motivation System Adoption Model) method [12]. This questionnaire will help measure the value of behavior intention to use and immersion. Statements will have six levels of agreement to avoid neutral responses with a Likert scale [13]. Six Levels of the agreement are described as follows.

1. Strongly disagree, has a value of 1

2. Disagree, has a value of 2

3. Slightly disagree, has a value of 3

4. Slightly agree, has a value of 4

5. Agree, has a value of 5

6. Strongly agree, has a value of 6 
Some statements in the questionnaire will be assessed in reverse. Some of the statements are constructed in negative form. Therefore, the six-level of the agreement are described as follows.

1. Strongly disagree, has a value of 6

2. Disagree, has a value of 5

3. Slightly disagree, has a value of 4

4. Slightly agree, has a value of 3

5. Agree, has a value of 2

6. Strongly agree, has a value of 1

This method is good for figuring out how well the pencak silat introduction can be delivered to the others with virtual reality games and their cognition about pencak silat. If the value of behavior intention to use is high, it means the user wants to learn more about the game and recognize pencak silat as something positive. In contrast, immersion value helps to indicate user experience about the game.

\section{$4 \quad$ Implementation}

The Game is implemented by using $\mathrm{CH}$ as the primary programming language and Unity3D as the game engine. Pencak silat movements are implemented as music notes. Players have to hit music notes with the correct pencak silat movement that has been prepared through JSON containing music charts or level. The music notes starting position will be randomized using the initial random positioning phase through the fisheryates shuffle method. The randomization method will only occur at the beginning of each play in the loading charts section. The pencak silat movement order each level is fixed based on the music chart. A music chart is a form of a string containing numbers representing which pencak silat move will be generated on the specified time based on Beat per Minute (BPM) calculation. The music note will move toward the player. Players are expected to get the highest score by hitting the music notes with the correct pencak silat movement and with the correct timing according to the rhythm. The cubeshaped object, which is the music note, has been given a trigger that judges the pencak silat movement. The game will end when the song stops. Players can see the scoreboard on the right side of the track lane that shows the score, current combos, and songs that are being played. The combo will reset when the player hits the music note falsely or passes the player. The game result will appear after the player the music stops. The highest accuracy of each level will be saved. Fig 2 illustrates the pencak silat movement, which is implemented in the game. 


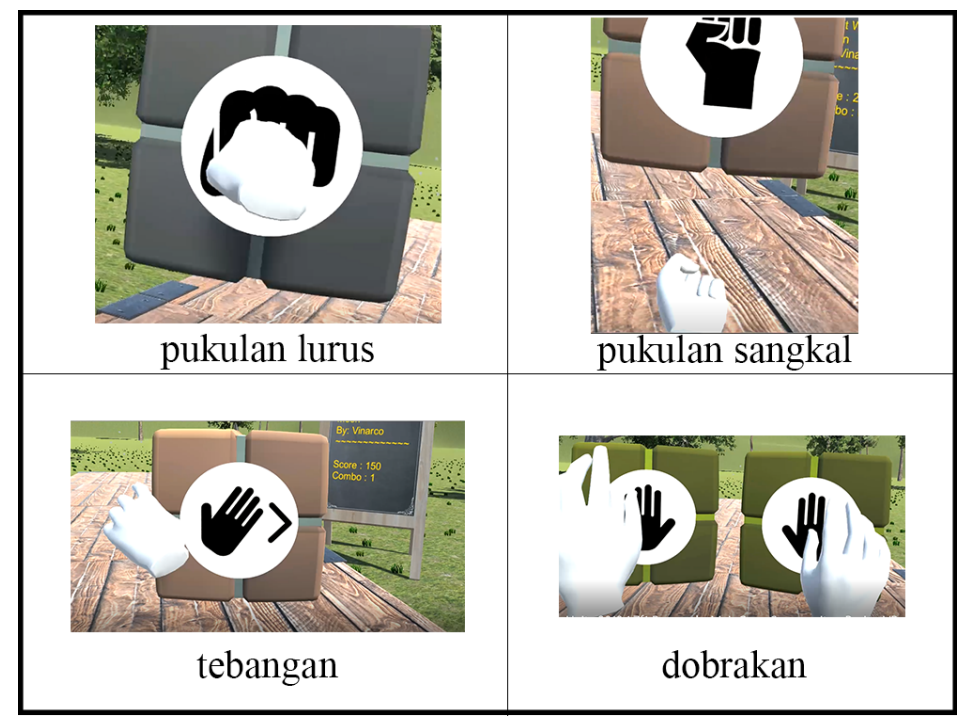

Fig. 2. Main game screenshot

\section{$5 \quad$ Evaluation}

An evaluation was done by distributing a questionnaire to 20 respondents using HMSAM to measure behavioral intention to use and immersion. These respondents have to play this Virtual Reality game in order to fill the questionnaire. Respondents were selected by purposive sampling aged over 18 years. Table 1 is obtained from the average calculation of 20 respondents [14].

Table 1. Calculation result with HMSAM modeling

\begin{tabular}{|c|l|c|}
\hline No & \multicolumn{1}{|c|}{ Category } & Average \\
\hline 1 & Perceived ease of use & $72.29 \%$ \\
\hline 2 & Joy & $78.47 \%$ \\
\hline 3 & Control & $71 \%$ \\
\hline 4 & Curiosity & $80.56 \%$ \\
\hline 5 & Perceived usefulness & $71.83 \%$ \\
\hline 6 & Temporal Dissociation & $70.83 \%$ \\
\hline 7 & Focused Immersion & $77 \%$ \\
\hline 8 & Behavioral Intention to Use & $78.61 \%$ \\
\hline
\end{tabular}

Perceived ease of use is the beginning of the value of joy, curiosity, perceived usefulness, and control, which obtained an average of $72.29 \%$, which means that respondents "agree" that the virtual reality game introduction of pencak silat is easy to use. The value of joy and curiosity influences the value of behavioral intention to use and immersion [12]. The joy value obtained was $78.47 \%$, and curiosity was $80.56 \%$. This is the basis for how players can feel the desire to play it back and be included in the game 
immersive. The control value obtained an average of $71 \%$ and supports immersion values [12]. The value of focused immersion is an average of $77 \%$, which means that respondents "agree" to be involved in the game in total. The average value of temporal dissociation is $70.83 \%$, which means that the player "agrees" to lose control of the running time while using the application. Behavioral intention to use the value obtained an average of $78.61 \%$, which can be interpreted that respondents "agree" if there is a desire to use it again. This value is encouraged by perceived usefulness value, with an average of $71.83 \%$ [12].

Based on the values obtained, players do not reject or view the pencak silat as something negative. However, players are interested in learning about pencak silat through virtual reality games. This can be a means of breaking the negative stigma of pencak silat from the community's perspective.

\section{Conclusion}

Based on research and evaluation that has been conducted, it can be concluded that the virtual reality game introduction to pencak silat with the fisher-yates shuffle method has been successfully designed and developed. The behavioral intention to use and user immersion values is obtained using the HMSAM (Hedonic-Motivation System Adoption Model) modeling. Calculation of behavioral intention to use obtained a result of $78.61 \%$. It can be concluded that the user "agrees" to re-use the virtual reality game introduction to pencak silat with the fisher yates shuffle method. The immersion value obtained by $77 \%$ shows that the players "agree" virtual reality game introduction to pencak silat with fisher yates shuffle methods players feel included in the game.

The acquisition of behavioral intention to use and immersion values shows the players "agree" to properly accept the martial arts martial arts. Players do not view negatively and accept martial arts as an element of the game. Players recognize pencak silat as something that has positive impacts. So, it can be concluded that the introduction of pencak silat virtual reality game with the fisher yates shuffle method is a success.

\section{$7 \quad$ Future Works}

Based on this research, future works that can be made to be used as further research are as follows.

1. The introduction of pencak silat can be implemented in the form of games with different genres. One possible genre is simulation or action.

2. Introduction to the movement of pencak silat, which involves a combination of foot and hand movements. Thus, the stance of pencak silat players will be included in the game.

3. The introduction of other Indonesian cultures, such as introducing batik into children's games to find out the types of batik and their origin to preserve Indonesian culture. 


\section{Acknowledgement}

This research and manuscript are funded and supported by Universitas Multimedia Nusantara, Tangerang, Indonesia.

\section{References}

[1] Iskandar and E. Kustiyah, "Batik Sebagai Identitas Kultural Bangsa Indonesia Di Era Globalisasi," Gema, vol. 30, no. 52, pp. 2456-2472, 2017.

[2] A. N. Weking, S. Suyoto, and A. J. Santoso, "A Development of Augmented Reality Mobile Application to Promote the Traditional Indonesian Food," International Journal of Interactive Mobile (iJIM), vol. 14, no. 09, p. 248, 2020, https://doi.org/10.3991/ijim.v14i09. 11179

[3] UNESCO, Decision of the Intergovernmental Committee: 14.COM 10.B.15, 2019. [Online]. Accessed on: Apr, 14. 2020. Available: https://ich.unesco.org/en/dec isions/14.COM 10.B.15

[4] O. Aj, Bunga Rampai Pencak Silat, 2010, Accessed on: Feb. 7, 2020. [Online]. Available: https://docplayer.info/49163710-Ebook-pencak-silat-bunga-rampai-pencak-silat-memahami-pencak-silat-secara-jernih-penulis-ochid-aj.html https://doi.org/10.5220/0007055901070110

[5] W. Istiono, Hijrah, and N. Nawaningtyas, P., "Education Games To Learn Basic Algorithm With Near Isometric Projection Method,” Int. J. Adv. Stud. Comput. Sci. Eng. IJASCSE, vol. 8, no. 7, pp. 6-10, 2019, https://doi.org/10.31227/osf.io/yuzn7

[6] J. C. Young, M. B. Kristanda and S. Hansun, "ARmatika: 3D game for arithmetic learning with Augmented Reality technology," 2016 International Conference on Informatics and Computing (ICIC), Mataram, 2016, pp. 355-360, https://doi.org/10.1109/iac.2016. 7905744

[7] T. Abdulghani, M. T. Jufri, and S. Mufti, "Pemanfaataan Teknologi Virtual Reality Untuk Game Labirin Berbasis Android,” Semin. Nas. APTIKOM, 2017, doi: 10.17605/OSF.IO/XJTBV.

[8] G. T. A. Kusuma, I. M. A. Wirawan, and I. K. R. Arthana, "Virtual reality for learning fish types in kindergarten," International Journal of Interactive Mobile (iJIM), vol. 12, no. 8, pp. 41-51, 2018, https://doi.org/10.3991/ijim.v12i8.9246

[9] R. S. Kriswanto, Pencak Silat. Yogyakarta: Pustakabarupress, 2015.

[10] M. Bostock, Fisher-Yates Shuffle, 14, Jan. 2012. [Online]. Available: https://bost.ocks.org/mike/shuffle/[Accessed: Feb. 7, 2020].

[11] F. Kurniawan and B. K. Fikria, "Game Bahari Menggunakan Algoritma Fisher Yates Suffle Sebagai Pengacak Posisi NPC,” Matics, vol. 7, no. 2, p. 71, 2016, https://doi.org/10. 18860/mat.v7i2.3281

[12] P. B. Lowry, J. E. Gaskin, N. W. Twyman, B. Hammer, and T. L. Roberts, "Taking 'fun and games' seriously: Proposing the hedonic-motivation system adoption model (HMSAM)," J. Assoc. Inf. Syst., vol. 14, no. 11, pp. 617-671, 2013, https://doi.org/10.17705/ 1 jais. 00347

[13] Riduwan, Skala Pengukuran Variabel-Variabel Penelitian. Bandung: ALFABETA, 2009.

[14] Daniel and G. Virginia, "Implementasi Sistem Pakar untuk Mendiagnosis Penyakit Dengan Gejala Demam Menggunakan Metode Certainty Factor," Jurnal Informatika, vol. 6, no. 1, pp. 25-36, 2010, https://doi.org/10.21460/inf.2010.61.82 
[15] Papadakis S, "Evaluating the Learning Process: The "ThimelEdu" Educational Game Case Study", Proceedings of the 12th International Conference on Computer Supported Education (CSEDU), 2020 - Volume 2, pages 290-298 ISBN: 978-989-758-417-6, https://doi.org/10. 5220/0009379902900298

[16] Bunchball. "Gamification 101: An Introduction to the Use of Game Dynamics to Influence Behaviour Gamification”, 2010.

[17] Papadakis, S, "Using Gamification for Supporting an Introductory Programming Course. The Case of ClassCraft in a Secondary Education Classroom", 2nd EAI International Conference on Design, Learning \& Innovation, 2017, https://doi.org/10.1007/978-3-319-76908$\underline{0 \_35}$

[18] Murdiono. M, Suyato, Rahmawati. E. N, Aziz. M. A, "Developing an Android-Based Mobile Application for Civic Education Learning", Vol 14, No. 16, 2020, p. 180, https://doi.org/10.3991/ijim.v14i16.14967

[19] Papadakis, S, "Evaluating a game-development approach to teach introductory programming concepts in secondary education". International Journal of Technology Enhanced Learning, 12(2), 127-145, 2020. https://doi.org/10.1504/ijtel.2020.106282

[20] Papadakis, S., Kalogiannakis, M., "Evaluating the effectiveness of a game-based learning approach in modifying students' behavioural outcomes and competence, in an introductory programming course. A case study in Greece". International Journal of Teaching and Case Studies, 10(3), 235-250, 2019. https://doi.org/10.1504/ijtcs.2019.10024369

\section{Authors}

Jansen Sampurna is a student in department of informatics, faculty of engineering and informatics, at Multimedia Nusantara University, Indonesia. E-mail: jansen.sampurna@student.umn.ac.id

Wirawan Istiono is currently a lecturer and researcher in faculty of engineering and informatics, Universitas Multimedia Nusantara and also serving as the head coordinator of the Game Development Laboratory. His research interests include requirements engineering in software application development, computer engineering, and human computer interaction. E-mail: wirawan.istiono@umn.ac.id

Alethea Suryadibrata is a lecturer in department of informatics, faculty of engineering and informatics, at Multimedia Nusantara University, Indonesia. E-mail: alethea@umn.ac.id

Article submitted 2020-08-11. Resubmitted 2020-10-04. Final acceptance 2020-10-08. Final version published as submitted by the authors. 